\title{
Study on the Factors of Photographic Images Sharing among Online Community
}

Mohd Pirdaus B. Mat Husain ${ }^{1}$

${ }^{I}$ University College of Yayasan Pahang

\begin{tabular}{l}
\hline \hline ARTICLE INFO \\
\hline \hline Article history: \\
Received: August 9, 2021 \\
Revised: August 13, 2021 \\
Accepted: September 13, 2021 \\
\hline Keywords: \\
Photography, \\
Communication \\
Viral, \\
Narrative, \\
FGD
\end{tabular}

Clonflict of Interest:

None

Funding:

None

\begin{abstract}
Communication technology has played an important role in disseminating information to the public. This information includes the dissemination of photographic images seen in various forms. The Internet is also seen as a tool to convince the public of an event. Therefore, the main objective of this study is to see what are the main factors that influence students to tend to do the sharing of photographic images in the online community. The method used for this research was a focus group discussion (FGD) consisting of 21 informants aged 20 - 25 years old. All informants are students of the University College of Yayasan Pahang (UCYP). To see the basis of the spread of a photographic image, Narrative Theory has been used to support this study. The findings of the study found that several factors are seen as the main factors of image sharing online. Among them is the use of themes in the image and the emotions found in the image. In addition, 'subject matter' and ethics is an important factor that is evaluated before a photographic image is shared. However, some informants do not take any action instead are more interested in sharing photographic images. This is due to the lack of exposure to photography and the use of the media itself.
\end{abstract}

Corresponding Author: Mohd Pirdaus B. Mat Husain, Faculty of Creative Art, University College of Yayasan Pahang, 26060, Kuantan, Pahang, Malaysia, E-mail: pirdaus@ucyp.edu.my

(C) Mohd Pirdaus B. Mat Husain

This is an open access article under the CC BY-SA 4.0 international license.

\section{Introduction}

Today's society is dominated by the visual from all over the world. Introduction to communication technology and coupled with the development of digital photography has a huge impact on society. The impact from the visual always is able to communicate with society and it's become more important. Furthermore, it creates emotional effects and invites the participation of different opinions from society. Photographic images are basically identified by each of those who see them. However, it is also difficult to explain textually (Nadzri, et al 2014). According to Mustaffa Halabi (2011), by using photography as a medium in communication, photography has the ability to create image documentation in the form of realistic or reality that is the subject recording facts, moments of events and events can be maintained in the form of a photo. Nagib Padil (2013) stated that one of the most important things in the phenomenon of the existence of the photographic process to this day is the visual language that uses pictures or symbols in presenting a message or meaning also equals accuracy and experience as in photo recording. Liz Well (2015) states that photographic images have their importance in conveying meaning and it is not just an image but able to convey emotions as soon as the image is produced even if the image is just a display of objects, society, and even place. The role of the photographic image visually is indisputable.

Mustaffa Halabi (2011) emphasizes that each visual image content is categorized into two parts. The first is known as the realistic function or the sense that serves to convey the truth or any things that can be seen in the real-world reality. The second is known as interpretation or perception which serves the purpose for which the image is interpreted and analyzed. In her writing, " Photography: Its Significance and Values in Education, has clearly discussed the importance of photography or visual image in everyday life especially in 
contributing to the context of visual culture. He further stated that society often sees photography as a hobby that lacks intellectual values in everyday human life. Photography is considered easy to record any event by simply pressing the camera. It is not necessary to use the brain or any human intellectual property in taking pictures. As for the aspect of reality however, Mustaffa Halabi argues that photography has its own meaning and values in conveying meaning that has its own intellectual characteristics comparable to other means of communication. Norziha, et al. (2009) stated that visual communication is defined as a form of communication that uses visual symbols such as pictures and graphics to express ideas and convey meaning. It has its own strengths and values in our daily lives. The use of communication technology, which is seen to be growing from time to time has made any information or media content sent and received by the community group very quickly, especially those who have the advantage of Internet network access. Technology is also interpreted into advanced scientific studies in terms of the use of sophisticated electronic equipment. Van Dijck (2008) stated that human communication has significant changes as a result of technological developments or communication revolution in the form of technical or structural. Internet technology has changed the way society reacts and has changed perceptions and communication space Huang et al. (2016). The existence of this technology allows photographic images to be spread so quickly and easily with low-cost savings. This includes the spread of photographic images of a boy, Aylan Kurdi who drowned in Turkish waters, which is a worldwide phenomenon. The image goes viral around the world and created an awareness of the war refuges crisis.

\section{Viral}

Viral can be states that a issues that a spread throughout the world rapidly. Nahon and Hemsley (2013) stated that viral can be something that stands out as remarkable in a sea of content. Indeed, virality is one of the mysteries of the Internet era because it is difficult to know why certain songs, movies, video clips, or news articles gain sudden and wide popularity, while other ones that are similar in quality, content, and presentation (if not better) do not become viral (Ahmed Al-Rawi (2017). Viral emerges when communication technology are widely uses in the world. The communication technology such as Internet has gained a lot of attentions among society. As the Internet evolves, its users and uses grow and diversify globally. The Internet is not owned by anyone and is not controlled by any control center. Almost all of the content available on the Internet is used for knowledge, education and even entertainment. The three most popular activities among internet users are sending and receiving emails, reading messages in newsgroups and browsing the World Wide Web. Currently, it is reported that there are about 4.1 billion people who apply the internet worldwide and this number is expected to increase at a rate of 15 percent per month (Internet World Stats, 2020). The use of the Internet has sparked the transfer of traditional technology to the stunning digital era. To find the latest information in any aspect, internet users should press a keyword on the keyboard. It is in this global village that people exchange information, news and services regardless of skin color, race or ideology. In short, according to Miller (2011), the sophistication of this technology can facilitate the communication process especially in organizational communication. The development of communication technology has enabled information to be sent and received quickly. This facility has increased the use of the internet in sharing activities of any form of entertainment and this includes the sharing of photographic images online. Things happen without wasting time and in turn make the image 'viral' worldwide. Berger \& Milkman (2012) states that it is crucial to understand what are the factors that make the photographic image 'viral' by looking in depth at the real meaning behind the image.

\section{Problems Statement \& Objectives}

Photography is a representation of the real situation of something that has happened or will happen. Each image produced has a clear meaning seen and the emotions found in each image of the photography (Husaini, 2013). The use of photography can form relationships in the social structure of society. When the audience sees a photographic image, it will indirectly form a subjective meaning in interpreting the meaning of the image. Photography is usually seen as a link to a story, but the image of photography is the main attraction to attract the attention of the audience compared to other visuals (Adzrool et al. 2010).

As such, the development of communication technology has encouraged the online community to share photographic images that they feel are worthy of sharing with friends and spread widely in the realm of social media. What is seen is a photographic image that contains a specific narrative. In the enthusiasm of the audience to share the image they see, there is also concern about how the image is able to tell the truth and not to something that is slanderous, rumored and the validity of the image. The priority of media literacy is also actually able to be a factor to understand each particular photographic image and understand what the real meaning behind each visual (Shahizan et.al 2015). Each image shared by the audience has certain characteristics. Sibbet (2008) states that an image that displays about social life is an artifact that requires 
clearer observation and understanding to understand what the real meaning behind the image is. Alesich (2007) states that the image shared by the audience can communicate with other audiences and beyond. Ross and Lester (2011) argue that photographic images are capable of adding information to the actual narrative, it can also serve as a structure for text that is capable of influencing the true meaning behind the image. However, the factor of what derives the online community to share photographic images is still need to be explored. Therefore, the main objective of this study is to see what are the main factors that influence students to tend to do the sharing of photographic images on the online community.

\section{Narrative Theory}

The theory that been used for this study is the narrative theory founded by Walter Fisher, which states that communication will be more meaningful when an event or visual is seen and told (Fisher, 1987). Audiences should understand storytelling that has a beginning, middle, and an end. Fisher believes that all forms of communication seen visually are as stories shaped by history, culture, and character. Narrative is a meaning that has meaning with the construction of various meanings either implicitly or explicitly. According to Prince (2003), narrative means a narration or more events that happened or did not happen by one, two, or several narrators to one, two, or several recipients of the story. Fludernik (2009), on the other hand, describes the narrative as a conjunction or discourse on the story that can be presented through various forms of media.

For this study, narrative theory has been used in exploring the main factors of what derives the online community tend to share the photographic images. This is because each photographic image has a story, which is a narrative story and what is actually a story behind every image they seen.

\section{Methodology}

Focus group discussion is frequently used as a qualitative approach to gain an in-depth understanding of social issues. The method aims to obtain data from a purposely selected group of individuals rather than from a statistically representative sample of a broader population. This research used qualitative method, which is called as Focus Group Discussion (FGD). Kruger \& Casey (2009) explain that focus group interview is a form of qualitative research in which a group of informants are interviewed about their perceptions, their opinions, their beliefs and their attitude to a particular issue or issue. The selected group will be given a topic or issue to discuss and share information and ideas together with the purpose of this issue clearly understood.

The design of this research is as following figure:

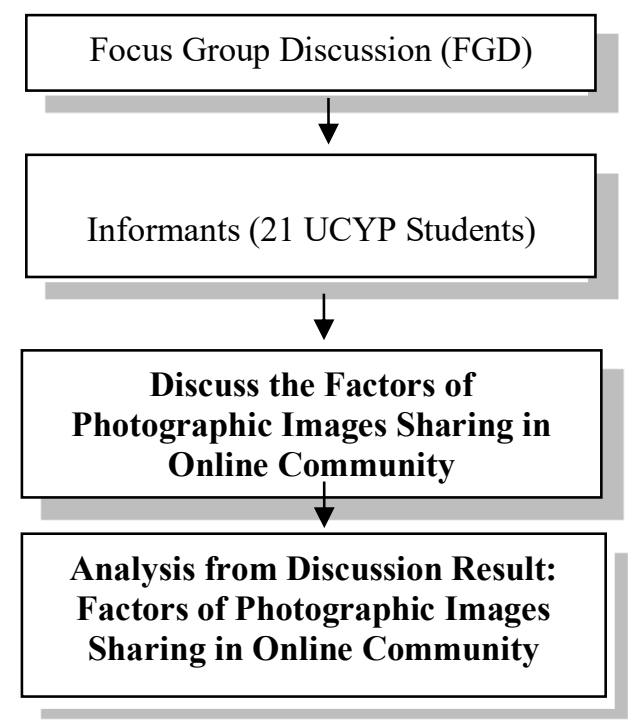

Figure 1.0 : Focus Group Discussion Research Design

\section{Research Subject}

Creswell stated that the sample size for a phenomenological study can be ranged from 1 to 325 , but a sample size from 3 to 10 was recommended (Creswell, 2009) in order to find the appropriate informants, chain sampling technique which could identify cases of interest from people who know what case information-rich are was used. Therefore, the researcher selected 21 informants which are divided into three groups. The first group is students who exposed to the internet more than 8 hours a day; second group is students who are 
exposed to the internet $8-16$ hour a day and last group students who were exposed to the internet below than 8 hours a day. The range of their ages is from 20 to 25 years old. All of the informants are University College of Yayasan Pahang (UCYP) students. Below are the samples of informants divided into three groups.

\begin{tabular}{|c|}
\hline $\begin{array}{c}\text { Students who } \\
\text { exposed to the } \\
\text { internet more than } 8 \\
\text { hours a day }\end{array}$ \\
\hline A (Frequent) \\
\hline
\end{tabular}
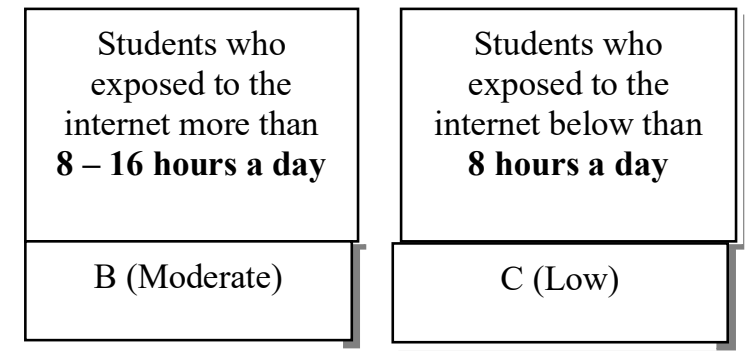

Figure 2.0: Research Samples

\section{Results \& Discussion}

Most of the informants state that they know what photography is and how photography is able to deliver information or messages. Through the main question which is to find out their level of knowledge on key issues conducted during the first session of FGD, all six informants form the three different groups have stated that they are aware of photography and how photography can evoke emotion, and the meaning of photography itself.

\section{Informant "Photography is whatever that we capture using our camera." \\ A1}

Informant "Photography is like photo that we shoot using our camera, for example photo in newspaper." B3

Informant "For me, all the picture that we see la."
B6
$\begin{array}{ll}\text { Informant "Photography is my passion sir, and what I understand is when we shoot a photo like photo } \\ \mathrm{C} 2 & \text { when we go to holiday." }\end{array}$

Informant "If everyone likes photography, take pictures here and there with our phone and edit." A4

Based on the answers obtained from the result of the main question, it was found that the average informant actually understands what is meant by photography which is the main issue in this study. This is because it is possible that all informants have a Smartphone that is seen to have camera function and this is a factor they know about photography in general. From the FGD, several factors have emerged about the factors that derived informants to do a photographic image sharing in online communities. The first factors that encourage informants to share a photographic image online are narrative factors. The narrative factor is reflecting their knowledge about the real meaning that contains in every image.

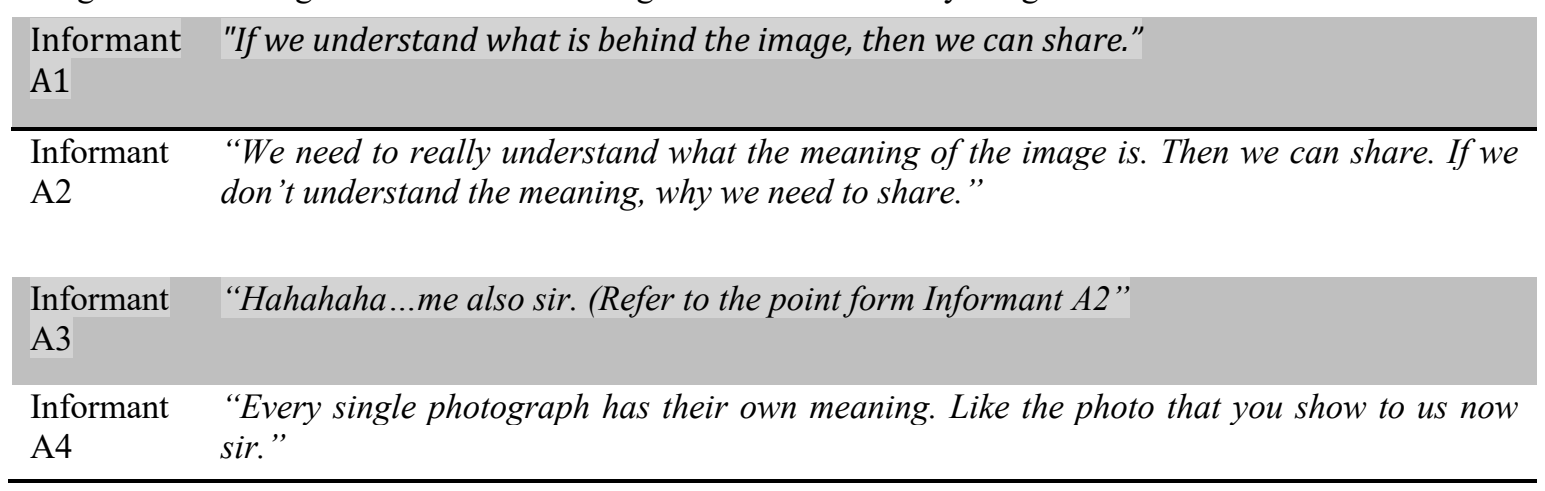


Results showed that informant's form the group A, which is a group that is exposed to the internet more than 8 hours a day really understands that narrative factor, is important in comprehending every single image. It is important to determine whether the samples are really aware about the issues that will be discussed further in the research. The second factor is the internet exposure among the informants. It reflects their interest to involve in sharing activity in online communities as the result from FGD below shows the internet with the medium as social media has sparked their interest in sharing photographic images.

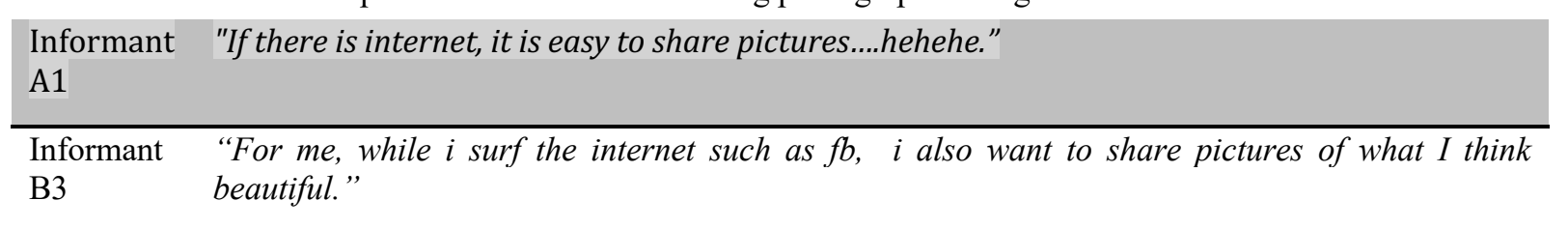

\begin{tabular}{|c|c|}
\hline $\begin{array}{l}\text { Informant } \\
\text { B4 }\end{array}$ & "like to share pictures using instagram and facebook. People can see what we do." \\
\hline $\begin{array}{l}\text { Informant } \\
\text { C3 }\end{array}$ & $\begin{array}{l}\text { "It is the internet that makes us want to share the pictures we see on the internet, especially whe } \\
\text { there is wifi..hahaha" }\end{array}$ \\
\hline
\end{tabular}

For informants, the new technology of new media nowadays has helped them to communicate with others. It can be said that almost all the informants interviewed are users of the new media. This is in line with the study by Hasim \& Salman (2010) who stated that interpersonal relationships and social networks as well as perceptions of the benefits of the internet have a positive influence on the users themselves. Third factor is emotion. Emotion is known as one of the most powerful elements in photography.

\begin{tabular}{|c|c|}
\hline $\begin{array}{l}\text { Informant } \\
\text { A1 }\end{array}$ & "I just want to share pictures that contains emotions, sad story..hahaha" \\
\hline $\begin{array}{l}\text { Informant } \\
\text { A3 }\end{array}$ & "Image that have a old man, or family live in poverty. It's very sad sir..like Ustaz Ebit Lew.." \\
\hline $\begin{array}{l}\text { Informant } \\
\text { B2 }\end{array}$ & $\begin{array}{l}\text { "If I have a picture that telling something like poverty or people who have a hard time... look at it } \\
\text { too..usually this kind of image I will share because so it really has an effect on me." }\end{array}$ \\
\hline $\begin{array}{l}\text { Informant } \\
\text { B4 }\end{array}$ & $\begin{array}{l}\text { "The effect that makes us feels like we want to help. I want to do more, I really can't... if I can } \\
\text { share is ok... like a picture of a bad person... just share it, who knows can help other } \\
\text { people..heheh." }\end{array}$ \\
\hline
\end{tabular}

However, the opinion of the informant from group 3, which is the group that is less exposed to the internet use, shows a slightly different answer than the informants of groups 1 and 2 .

$\begin{aligned} & \text { Informant } \\ & \mathrm{C} 1\end{aligned}$
$\begin{aligned} & \text { Informant } \\ & \mathrm{C} 3\end{aligned}$
$\begin{aligned} & \text { Informant me sir, I will share the artist image like Blackpink or K-Clique" } \\ & \mathrm{C} 4\end{aligned}$
$\begin{aligned} & \text { Informant just don't care sir..coz I really don't spend much time online." } \\ & \text { "I rarely surf the internet, but if I get a scary picture or a sexy picture, I just share..hehehe" }\end{aligned}$


Based on this result, research results on the third factor which is emotion have indicated that informants with more exposure to the internet are able to really understand the emotion that contains in every single photographic image rather than informants form the group that have a less exposure to the internet. Another factor that encourages informants to share a photographic image online is ethics. Ethics can be defining as a standard of moral behavior that are accepted by society as right versus wrong (Nickels et al. 2008). Webster (2012) also defines "ethics" as, "the code of good conduct for an individual or group," and lists synonyms as, "morality, morals, principles, and standards. It can be seen in the table below.

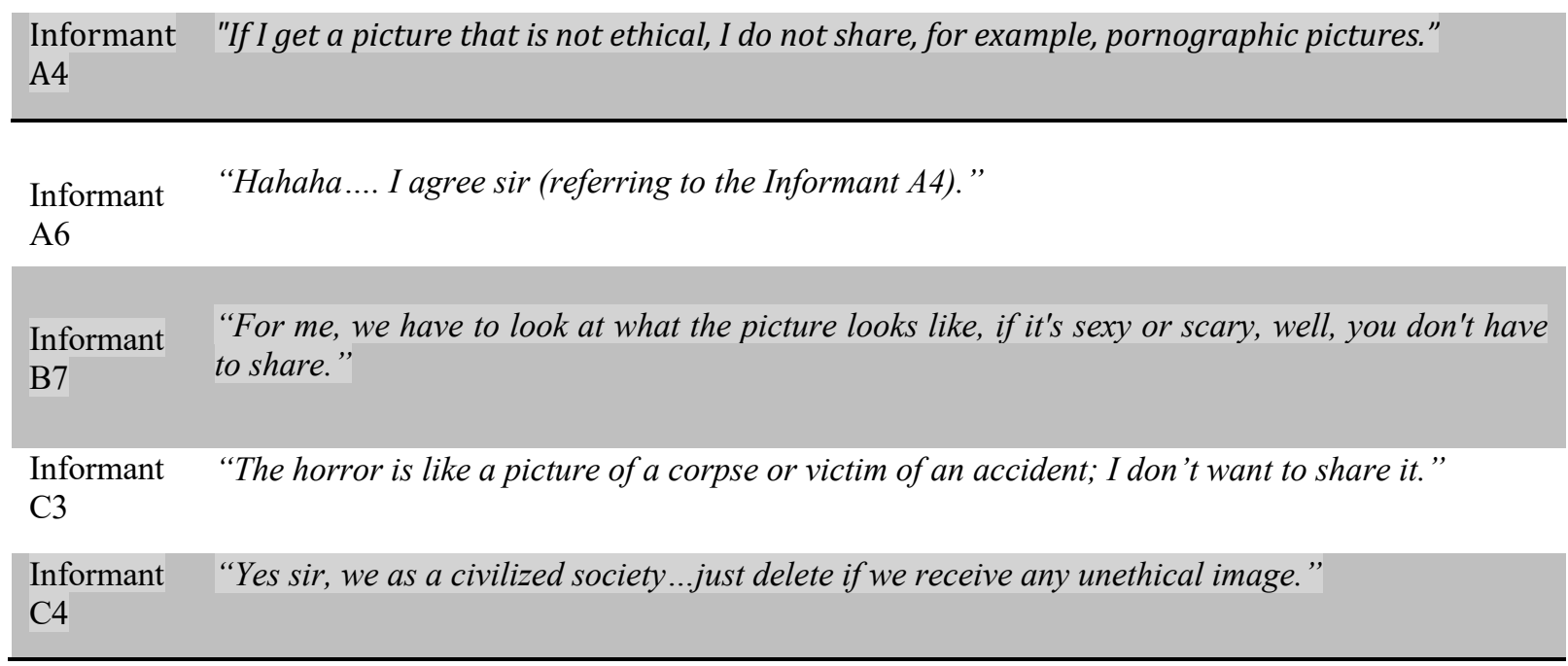

Result indicated that all the informants from the three different groups agree that ethics is the most important factor that persuades them either to share or not. When we take an ethical approach to photography, we increase our awareness of the impact that we are having on the world through the images we produce, and we are better able to focus our impact in a meaningful way. It can be said that most informants know that ethics is a factor that is needed to be considered before sharing any photographic image. Mohd Nor Shahizan (2015) states that the knowledge of media literacy is able to be a factor to understand each particular photographic image and understand the real meaning behind each visual. The last factor that encourages informants to share a photographic image online is the subject matter itself. Glenn (2019) defines subject matter in photography is the main object that photographed or related to the primary focus point interest.

\begin{tabular}{ll} 
Informant & "The subject matter need to be 'real' sir." \\
\hline Informant & $\begin{array}{l}\text { "Subject matter must be real live sir, for example, a child playing with her toy or just like picture } \\
\text { you show to us now." }\end{array}$ \\
$\begin{array}{l}\text { Informant } \\
\text { B7 }\end{array}$ & "Just like this picture sir (refer to the image of Aylan Kurdi)" \\
Informant & "For me sir, real subject will attract people to share it and make it viral. I remember sir, image of \\
C3 & nature in Kashmir, very beautiful."
\end{tabular}

\section{Informant "Subject is very important sir. It is the main point of interest in every photograph." \\ C4}

Can't be denied that without a true and precise subject matter in photography, the image will look unattractive and unable to convince the audience regarding the issues. In addition, the main subject of a photographic image plays an important role in become one of the deciding factors weather the image can be shared by the online community or not 


\section{Conclusion}

The main finding of this study has found that the narrative, ethics, emotion \& subject matter become a major factor of a photographic image sharing among online communities. This is because most of the informants' state that the narrative, ethics \& subject matter of an image is a factor in whether the image will be shared with others or not. This study also found that each image has a specific meaning, and it is interpreted differently by the audience and in this study, photographic images are interpreted differently among informants.

\section{References}

Al-Rawi, Ahmed. (2017). Viral News on Social Media. Digital Journalism. 7. 10.1080/21670811.2017.1387062.

Berger, J., \& Milkman, K. L. (2012). What makes online content viral? Journal of Marketing Research, 49(2), 192-205

Journal of Marketing Research, 49(2), 192-205

Huang, J., Baptista, J., \& Newell, S. (2015). Communicational ambidexterity as a new capability to manage social media communication within organizations. The Journal of Strategic Information Systems, 24(2), 4964.

Husaini, Y (2013). Social Commentary on photographic Images ,Proceeding, Contemphoto13, Turkey:

Dakam.

https://www.internetworldstats.com/

Ismail, Adzrool \& Isa, Kamarudzaman \& Azahari, M.H.H. (2010). An interpretation of photography as an art and communication. 1350-1352. 10.1109/CSSR.2010.5773750.

Miller, Katherine. (2011). Organizational Communication: Approaches and Processes.

Mustaffa Halabi Azahari. (2011). Photography: Its Significance Strands and Values in Education. Shah Alam: University Press.

Nadzri Mohd Sharif,Mohd Nor Shahizan Ali \& Mohd Yusof Hj Abdullah. (2014). Literasi Visual Dalam Imej Digital Fotografi Forensik Penyiasatan. Malaysia Journal Of Communication.

Nagib Padil. (2013). Peranan Pemujukan Medium Fotografi di Media Cetak dan Media Online Bagi Penggunaan Aktiviti Kempen Pada Pilihan Raya Umum.Proceeding of the World Conference on Integration of Knowledge, WCIK 2013

Nahon, Karine \& Hemsley, Jeff. (2013). Going Viral.

Norziha Megat Mohd. Zainuddin, Halimah Badioze Zaman and Azlina Ahmad. (2009) Visual Informatics: Bridging Research and Practice. First International Visual Informatics Conference, IVIC 2009 Kuala Lumpur, Malaysia, November 11-13, 2009 Proceedings.Springer.

The Merriam-Webster Online Thesaurus, Ethics, http://www.m-w.com/cgibin/thesaurus?book $=$ Thesaurus\&va $=$ ethics $\& x=0$ (Retrieved on 15 January 2021)

Van Dijck, José. 2008. "Digital Photography: Communication, Identity, Memory." Visual Communication 7 (1): 57-76. doi:/10.1177/14703572070848

Wells, Liz. 2015. Photography: A Critical Introduction. London: Routledge Looking and thinking across students' photographs from the U.K., Zambia and Indonesia. Journal of Research in Special Education, 7(1), 23-35. doi: 10.1111/j.1471-3802.2007.00078.x 